\title{
Patterns of secretion of GnRH, LH and FSH during the postovulatory period in mares: mechanisms prolonging the LH surge
}

\author{
C. H. G. Irvine and S. L. Alexander \\ Animal and Veterinary Sciences Group, Lincoln University, New Zealand
}

\begin{abstract}
To study the mechanisms responsible for the unusually slow decline of the ovulatory LH surge in mares, secretion patterns of $\mathrm{GnRH}, \mathrm{LH}$ and FSH were monitored in pituitary venous blood collected every 2 or $5 \mathrm{~min}$ for $10.5-18.0 \mathrm{~h}$ from five mares on the third $(n=4)$ or fifth day after ovulation (first sampling period). To determine the effectiveness of progesterone negative feedback, mares were then given a luteolytic dose of a prostaglandin analogue $\left(\mathrm{PGF}_{2 \alpha}\right.$ ) and pituitary venous sampling (every 2 or 5 min for $16 \mathrm{~h}$ ) recommenced 20-22 h later (second sampling period). During the declining arm of the LH surge, large peaks (detected by the Cluster algorithm) of concurrent LH and FSH secretion occurred infrequently, with four peaks being detected in a combined sampling period of $75 \mathrm{~h}$. Outside the peaks, LH or FSH secretion continued (as assessed by a pituitary to jugular-venous concentration ratio $\geq 1.25$ ) during $46 \% \pm 13$ or $40 \% \pm 10$, respectively, of the sampling period. GnRH immunoactivity was detected during each spontaneous gonadotrophin peak, but at other times was generally at assay sensitivity. After $\mathrm{PGF}_{2 u^{\prime}}$ plasma progesterone fell (ng $\mathrm{ml}^{-1}$, mean $\pm \mathrm{SEM}$; first sampling period: $8.6 \pm 0.8$; second: $2.0 \pm 0.3 ; P=0.001$ ) and the frequency of $\mathrm{LH}(P<0.05)$ and FSH $(P<0.02)$ peaks rose, with 28 peaks detected for each hormone in a total of $80 \mathrm{~h}$ sampling. Peaks in LH were smaller during the second period, with decreases observed in maximum $(P=0.027)$ and mean $(P=0.025)$ secretion rates. Maximum $\mathrm{GnRH}$ secretion rate during peaks also declined $(P=0.010)$; however, the decrement $(-30 \pm 6 \%)$ was less than that in maximum LH secretion rate $(-82 \pm 5 \%$; $P=0.040$ ), suggesting that other factors contribute to the reduced $\mathrm{LH}$ peak amplitude. In summary, gonadotrophin peak frequency during the downswing of the surge in mares is slow, as in the midluteal phase, and the slow rate of decline in peripheral gonadotrophin concentrations is due, at least in part, to continued secretion between pulses. Moreover, progesterone negative feedback is highly effective in early dioestrus, in that lessening it without complete removal markedly accelerates gonadotrophin pulse frequency.
\end{abstract}

\section{Introduction}

The ovulatory LH surge of the mare is unique in that it continues for several days after ovulation. In a typical mare, peripheral LH concentrations peak 1-2 days after ovulation and then fall slowly to reach low dioestrous concentrations approximately 4 days later (Ginther, 1992). It is thought that this prolonged increase in $\mathrm{LH}$ is important for establishing the corpus luteum (Ginther, 1992). A possible explanation for the slow decline of the ovulatory surge is that LH pulse frequency remains rapid, as it is before ovulation (Irvine and Alexander, 1994), tapering off only gradually. In ewes, LH pulses occur approximately hourly on the day after ovulation (Clarke et al., 1987a) but this may be due to the slow postovulatory rise in plasma progesterone in this species (Hauger et al., 1977). Numerous studies have shown that high progesterone concentrations act at the hypothalamus and lead to reduced LH pulse

Received 17 June 1996. frequency (for example, Goodman and Karsch, 1980; Soules et al., 1984). Plasma progesterone increases more rapidly after ovulation in mares than in ewes (Ginther, 1992), being significantly above oestrous values between $12 \mathrm{~h}$ and $24 \mathrm{~h}$ after ovulation (Townson et al., 1989). It may then be that the hypothalamus in mares responds relatively slowly to the rising progesterone negative feedback.

Because of the long circulatory half-life of gonadotrophins in mares (Irvine, 1979), detecting high frequency peaks in peripheral blood is difficult (Alexander and Irvine, 1987; Silvia et al., 1995). Therefore, we have used our non-surgical technique for collecting pituitary venous blood (Irvine and Alexander, 1987) to monitor secretion patterns GnRH, LH and FSH in mares during the declining arm of the ovulatory surge. We then examined the effectiveness of progesterone negative feedback early in dioestrus by giving mares a luteolytic dose of prostaglandin $\mathrm{F}_{2 \alpha}\left(\mathrm{PGF}_{2 u}\right)$ and observing hormone secretion patterns as progesterone concentrations declined. The aim was to gain insight into the relationship between $\mathrm{GnRH}, \mathrm{LH}$ and 

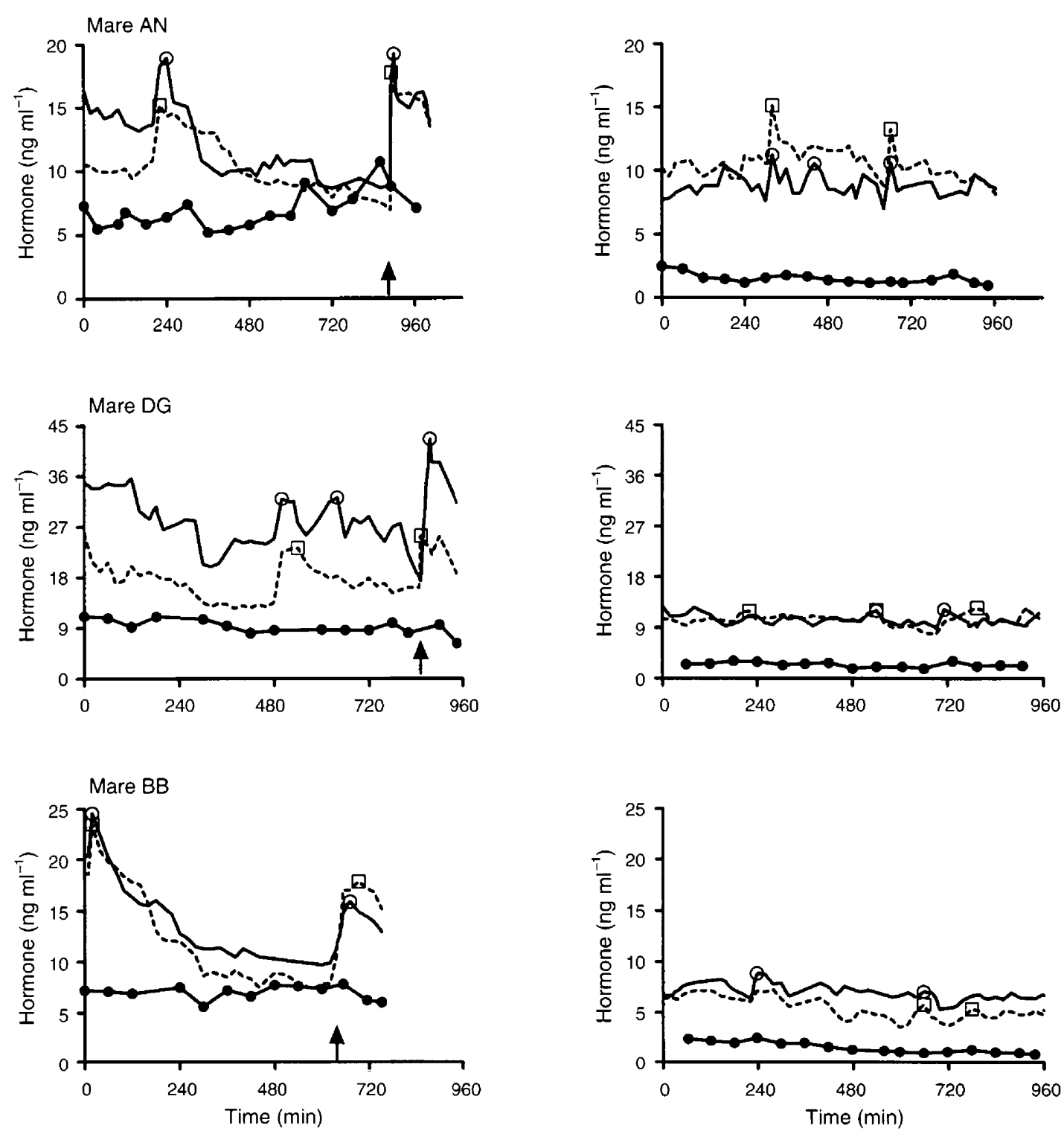

Fig. 1. Continued on following page

FSH secretion patterns and progesterone negative feedback in the immediate postovulatory period.

\section{Materials and Methods}

\section{Animals and experimental procedure}

Five normally cyclic Standardbred mares, aged 5-19 years, were used in this study, which was performed in the middle of the physiological breeding season. The ovulatory cycles of the mares were synchronized to some extent by administering a luteolytic dose of a PGF ${ }_{2 \Downarrow}$ analogue (cloprostenol; 'Estrumate', Coopers Animal Health; $250 \mu \mathrm{g}$ i.m.) during the mid- to late-luteal phase. Follicular activity was then monitored daily by palpation per rectum and sexual receptivity was determined by exposure to a vigorous stallion. On the morning of day 3 $(n=4)$ or day 5 (Mare SK) after ovulation (= day 0$)$, mares were placed in an open barn to which they had been accustomed and each was fitted with a cannula $(40 \mathrm{~cm} ; 7 \mathrm{~F})$ which was inserted into a superficial facial vein and advanced along a venous pathway unique to equids into the intercavernous sinus (ICS) (Irvine and Alexander, 1987). This nonsurgical procedure, which enables collection of pituitary venous blood, was performed under local skin anaesthesia with the mare lightly and briefly tranquillized (xylazine; 'Rompun', Bayer NZ Ltd, Auckland; $0.2 \mathrm{mg} \mathrm{kg}^{-1}$ i.v.) and has been approved by the Lincoln University Animal Ethics Committee. A cannula (16 gauge; $13.3 \mathrm{~cm}$; Angiocath, Deseret Co., Sandy, UT) was also placed into a jugular vein.

Starting between 16:00 and 21:30 h (that is, at least $7 \mathrm{~h}$ after cannula placement), pituitary venous blood was collected by syringe over $1 \mathrm{~min}$ every $5 \mathrm{~min}$ for $10.5-18.0 \mathrm{~h}($ mean $=15 \mathrm{~h}$ ), with a $2 \mathrm{~h}$ window of sampling at intervals of $2 \mathrm{~min}$ in three 

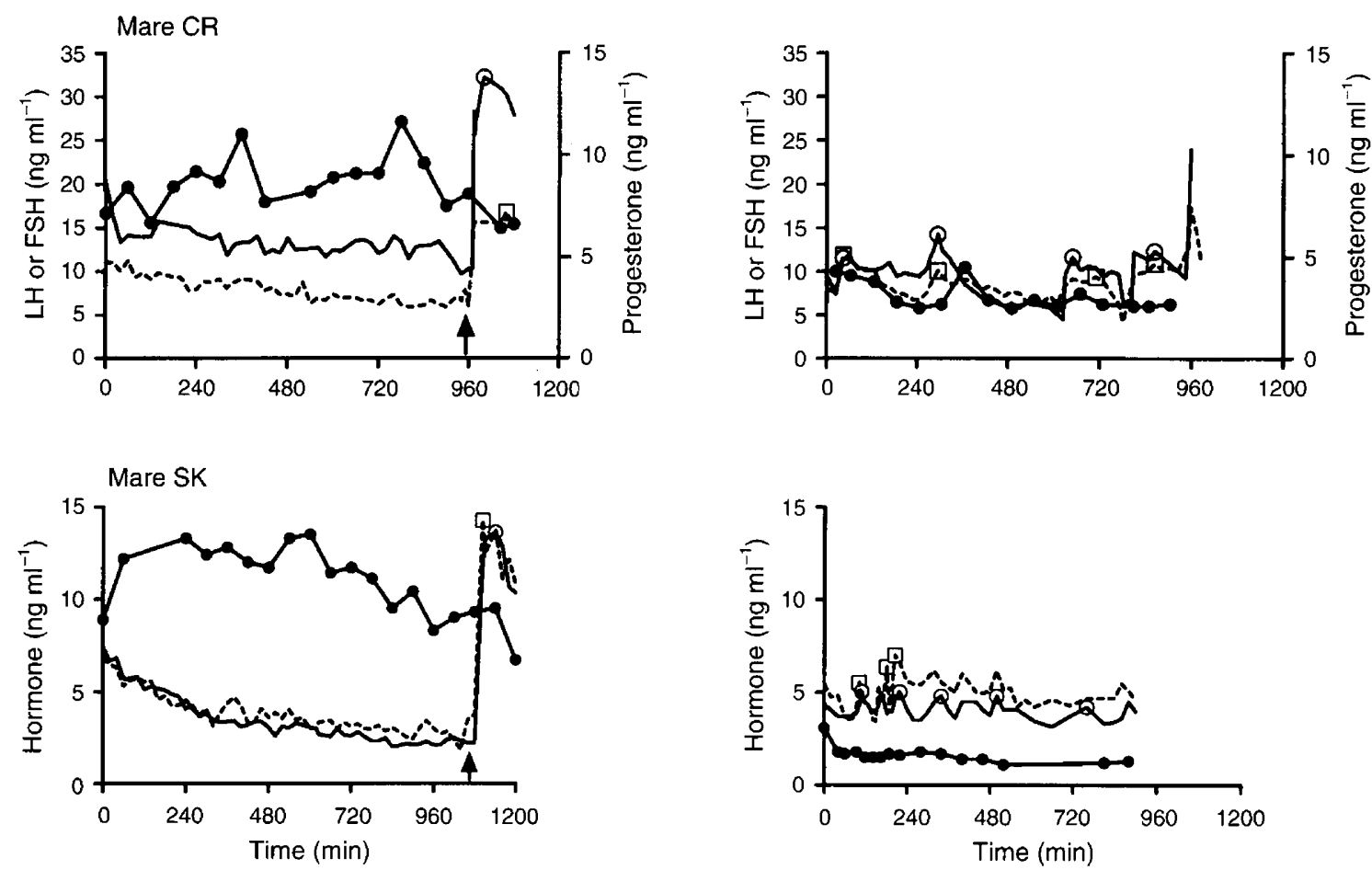

Fig. 1. Jugular LH (-), FSH (- - ) and progesterone $(-)$ concentrations in each of five early dioestrous mares sampled every $15 \mathrm{~min}$ before and immediately after prostaglandin $\mathrm{F}_{2 u}$ administration (arrow) (left panels) and again commencing 20-22 h later (right panels). All mares were first sampled on the third day after ovulation, except mare SK who was studied on the fifth day after ovulation. The maxima of gonadotrophin peaks as detected by the cluster algorithm are marked (LH: O) or (FSH: $\square$ ).

mares starting at 17:30-18:15 h. The ICS cannula was filled with heparinized saline $\left(500 \mathrm{U} \mathrm{ml}^{-1}\right)$ between samples. All mares were then given cloprostenol $(250 \mu \mathrm{g}$ i.m.) and pituitary venous blood sampling continued at 2 min intervals for $0.5 \mathrm{~h}$, and at $5 \mathrm{~min}$ intervals for a further $1.5 \mathrm{~h}$. Twenty (Mare SK) to twenty-two hours after cloprostenol administration, a second period of pituitary venous blood collection commenced, during which pituitary venous samples were taken every $5 \mathrm{~min}$ for $16 \mathrm{~h}$, with a $2 \mathrm{~h}$ window of 2 min sampling performed in all mares starting at 17:30 h. Jugular blood was collected every 15 min during periods of pituitary venous sampling. At the end of sampling on the second day, mares were given a bolus i.v. injection of $20 \mu \mathrm{g} \mathrm{GnRH}$ (Hoechst AG, Frankfurt) to assist in calculating ICS blood flow (Irvine and Alexander, 1987). Pituitary venous blood was collected at $-5,0,3,6,9,12$, 15, $20,25,30$ and $35 \mathrm{~min}$ after $\mathrm{GnRH}$ administration. Jugular blood was collected at $-5,0,9,15,25$ and 35 min. Mares were not restrained during blood sampling and ate hay and drank water ad libitum.

\section{Handling of blood samples}

Blood was placed into polystyrene tubes on ice. Bacitracin was not added to samples at collection as was our usual practice (Irvine and Alexander, 1993), because we have found that bacitracin causes slight interference in the GnRH assay, and preliminary tests showed that under the conditions of pituitary venous sampling, recovery of $\mathrm{GnRH}$ was similar with and without bacitracin. Blood samples were centrifuged for
$1400 \mathrm{~g}$ at $4^{\circ} \mathrm{C}$ within $30 \mathrm{~min}$ of collection. Although the heparinized saline was discarded from cannulae before each sample, sufficient heparin remained to prevent coagulation. Plasma was stored at $-20^{\circ} \mathrm{C}$ until assayed.

\section{Assays}

$\mathrm{GnRH}$ was measured by radioimmunoassay (RIA) as described by Irvine and Alexander (1993), except that $5 \mathrm{mg}$ EDTA was added to plasma $(0.9 \mathrm{ml})$ before extraction and an equivalent of $0.3 \mathrm{ml}$ plasma (not $0.5 \mathrm{ml}$ ) was assayed. The detection limit of the assay was $0.8 \mathrm{pg} \mathrm{ml}{ }^{-1}$ plasma. The mean intra-assay coefficients of variation $(\mathrm{CV})$ in the middle and low concentration range were $2.7 \%$ and $7.4 \%$, respectively. Mean interassay $\mathrm{CVs}$ were $6.9 \%$ and $11.8 \%$.

$\mathrm{LH}$ and FSH were measured by RIAs validated for use on horse plasma as described previously (LH: Shand et al., 1991; FSH: Irvine and Alexander, 1993). The detection limits were $0.24 \mathrm{ng}$ equine LH (Papkoff E263B) or $0.04 \mathrm{ng}$ equine FSH (Papkoff E276B) per tube. The mean intra-assay CVs were 6.1\% (LH) or $5.9 \%(\mathrm{FSH})$ in the concentration range in which most samples were diluted. When potency estimates were outside this optimal range, assays were repeated at a more favourable dilution. The mean interassay CVs were $10.1 \%(\mathrm{LH})$ or $10.4 \%$ (FSH). To compensate for interassay variability, selected samples from each assay contributing to the data from a given horse were reassayed together, and the results of individual assays were adjusted accordingly. Jugular samples were assayed with corresponding pituitary venous samples. 
Progesterone and oestrone sulfate were measured in selected jugular samples by specific enzymeimmunoassays, as described by Irvine et al. (1990) (progesterone) and Stabenfeldt et al. (1991) (oestrone sulfate). The detection limits were $0.35 \mathrm{nmol}$ $1^{-1}$ plasma (progesterone) or $0.5 \mathrm{ng} \mathrm{ml}^{-1}$ plasma (oestrone sulfate). The intra-assay CVs were $10.5 \%$ (progesterone) or $12.7 \%$ (oestrone sulfate). All samples from a given horse were assayed on the same microtitre plate.

\section{Statistical analyses}

Peak detection. Peaks in LH or FSH concentrations in pituitary venous and jugular blood were detected using the Cluster algorithm (Veldhuis and Johnson, 1986). Programme parameters were set to yield a false positive rate of $2.5 \%$ as estimated from data supplied with the programme, using symmetrical $t$ statistics and examining $2 \times 2$ clusters. The variance model used was based on assay replicates.

Calculation of hormone secretion rates. To enable calculation of hormone secretion rates, the blood flow at the tip of the ICS cannula was estimated as described by Irvine and Alexander (1993). Briefly, the amount (Q) of LH or FSH entering plasma during a major peak can be determined from (1) jugular or (2) pituitary venous data. From the jugular data, $Q$ is the difference in the peripheral plasma LH or FSH pool before and after each peak plus the loss from the pool during the peak interval. Loss was estimated by decay of the mean plasma pool over this period, using previously-determined constants for FSH or $\mathrm{LH}$ disappearance (Irvine, 1979). From the pituitary venous data, $Q$ is the mean difference between pituitary venous and jugular gonadotrophin concentrations at each sampling time $x$ the total blood flow past the cannula tip during the peak interval. Since blood flow is the only unknown, it can be calculated by equating the two methods for determining $Q$. For each mare, ICS blood flow was estimated during each endogenous, PGF $_{2 u^{-}}$ or GnRH-stimulated episode of $\mathrm{LH}$ and FSH secretion and the mean value for each day was then calculated.

The maximum $\mathrm{LH}$ or FSH secretion rates during clusteridentified peaks were determined as the difference between maximum pituitary venous and concurrent jugular concentrations multiplied by the ICS blood flow. Mean secretion rates were calculated in the same way but using the difference between mean pituitary venous and jugular concentrations. When GnRH concentrations were detectable during a gonadotrophin peak, the maximum $\mathrm{GnRH}$ secretion rate was estimated as the difference between the highest pituitary venous value observed and the jugular/solvent blank (usually close to the detection limit of the assay) $\times$ the ICS blood flow.

Statistical analyses. The effect of sampling period on gonadotrophin peak frequency was assessed by paired $t$ test, with data expressed as peaks per hour to compensate for variations in sampling duration. Changes with sampling period in maximum and mean gonadotrophin and maximum $\mathrm{GnRH}$ secretion rates during cluster-defined gonadotrophin peaks were also evaluated by paired $t$ test in the three mares having gonadotrophin peaks in both sampling periods. During the second sampling period, the relationship between gonado- trophin peak frequency and mean progesterone concentration was assessed by Spearman's rank correlation test. Gonadotrophin secretion rates and pulse frequencies were converted to logarithms, or $\log (x+1)$ for frequency data, for analysis. Results are given as arithmetic means \pm SEM.

\section{Results}

\section{Gonadotrophin secretion patterns in early dioestrus}

In all mares, jugular LH concentrations were increased when compared with mean mid-dioestrous values of approximately $2 \mathrm{ng} \mathrm{ml}^{-1}$ obtained in our laboratory (Irvine and Alexander, 1994), but fell steadily during the course of the first collection period (Fig. 1). These observations indicated that sampling occurred during the downward arm of the ovulatory surge. Mean progesterone concentrations were $8.6 \pm 0.8 \mathrm{ng} \mathrm{ml}^{-1}$. In pituitary venous blood, a total of four gonadotrophin peaks were detected in the five mares in a combined sampling period of $75 \mathrm{~h}$. Peaks were large episodes of concurrent $\mathrm{LH}$ and $\mathrm{FSH}$ secretion, which occurred once in each of Mares AN and DG, and twice in mare BB (Fig. 2) and were also detectable in jugular blood (Fig. 1). Outside cluster-defined peaks, LH or FSH secretion continued (as assessed by a pituitary venous to jugular concentration ratio $\geq 1.25$ ) during $46 \pm 13 \%$ or $40 \pm$ $10 \%$, respectively, of the sampling period. GnRH immunoactivity was detected during each peak of gonadotrophin secretion, but at other times was generally at the detection limit of the assay (Fig. 2). Gonadotrophin peaks in jugular blood were not associated with an immediate rise in progesterone concentrations (progesterone, $\mathrm{ng} \mathrm{ml}^{-1}$; before gonadotrophin peak: $7.3 \pm 0.6$; during the first $2 \mathrm{~h}$ after the peak: $7.1 \pm 0.5)$.

\section{Effect of administration of PGF $2 a$}

In all mares, $\mathrm{PGF}_{2 \alpha}$ induced a major and prolonged episode of concurrent LH and FSH secretion, which commenced $7 \pm 1$ min after administration (Fig. 2). GnRH immunoactivity was detectable after $\mathrm{PGF}_{2 u}$ in all mares. However, except in mare DG, measurable GnRH followed the initial gonadotrophin increase (Fig. 2), with the first detectable GnRH values observed $45 \pm 15 \mathrm{~min}$ (range $18-86 \mathrm{~min}$ ) after $\mathrm{PGF}_{2 a}$.

\section{Gonadotrophin secretion patterns during declining progesterone}

Mean progesterone concentrations during the second sampling period were $2.0 \pm 0.3 \mathrm{ng} \mathrm{ml}^{-1}$ and were lower $(P=0.001)$ than during the first period. At the start of sampling 20-22 h after $\mathrm{PGF}_{2 \alpha}$ administration progesterone concentrations were $3.0 \pm 0.4 \mathrm{ng} \mathrm{ml}^{-1}$ falling to $1.6 \pm 0.4 \mathrm{ng} \mathrm{ml}^{-1}$ $16 \mathrm{~h}$ later. During this period, no mare showed behavioural oestrus and oestrone sulfate concentrations did not rise ( $\mathrm{ng} \mathrm{ml}^{-1}$; period 1: $1.1 \pm 0.4$; period 2: $1.0 \pm 0.2$ ).

In pituitary venous blood, gonadotrophin peaks were detected in all mares (Fig. 2) and were almost always concurrent, with all but $2(93 \%) \mathrm{LH}$ peaks accompanied by an FSH peak (and vice versa). Peak frequency was greater than during Downloaded from Bioscientifica.com at 04/26/2023 11:32:48AM 

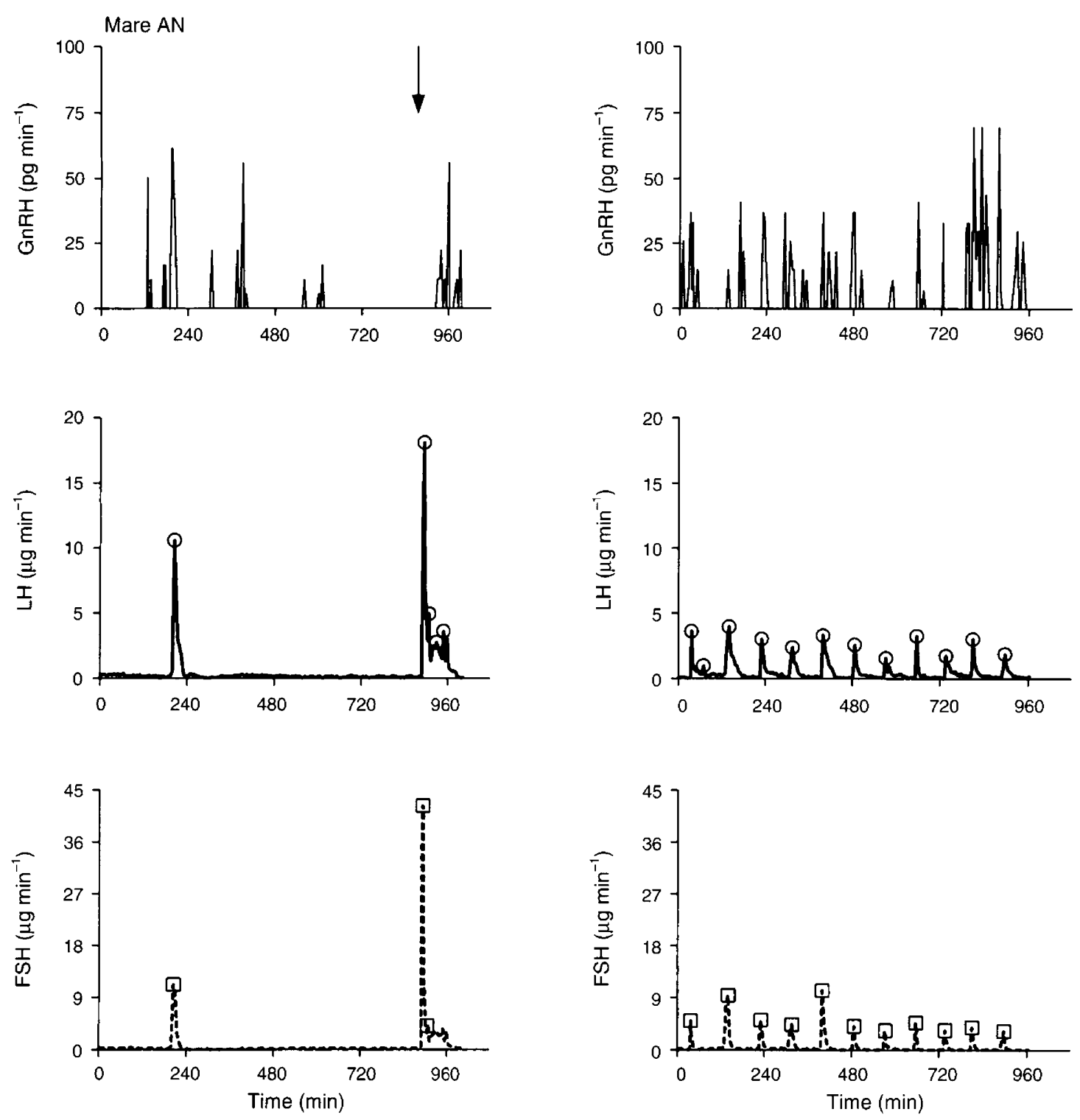

Fig. 2. Continued on following page

the first sampling period ( $\mathrm{LH}, P<0.05 ; \mathrm{FSH}, P<0.02$ ), with 28 peaks in each gonadotrophin observed in a combined sampling period of $80 \mathrm{~h}$. In each mare, pituitary venous gonadotrophin peaks appeared to be distributed evenly throughout the sampling period (Fig. 2) and peak frequency was unrelated to the mean progesterone concentration $\left(r_{s}=-0.36, n=5\right.$, NS, for both FSH and LH). Only $57 \%$ of pituitary venous LH and $50 \%$ of pituitary venous FSH peaks were detectable in jugular blood.

In the three mares in which gonadotrophin peaks occurred during both sampling periods, maximum $(P=0.027)$ and mean $(P=0.025) \mathrm{LH}$ secretion rates were lower during the second sampling period than the first (Table 1). Maximum and mean FSH secretion rates showed the same trend with day as did LH but the change did not reach significance owing to greater variability between mares (Table 1). GnRH immunoactivity could be detected during 65\% (13 of 20) of gonadotrophin peaks during the second sampling period. Maximum $\mathrm{GnRH}$ secretion rate during peaks was less $(P=0.010)$ during the second sampling period $\left(51.9 \pm 14 \mathrm{pg}\right.$ min $\left.^{-1}\right)$ than during the first $\left(72.3 \pm 14 \mathrm{pg} \mathrm{min}{ }^{-1}\right)$. Nevertheless, the decrement in $\mathrm{GnRH}$ secretion rate between days $(-30 \pm 6 \%)$ was less $(P=0.040)$ than that in maximum $\mathrm{LH}$ secretion rate $(-82 \pm$ $5 \%)$, and tended to be less than that in FSH $(-77 \pm 12 \%)$.

\section{Discussion}

Collection of pituitary venous blood showed that the unusual slowness of the downswing of the ovulatory LH surge in mares was not due to continued high frequency peaks of GnRH and gonadotrophin secretion. Rather, spontaneous release was characterized by infrequent, high amplitude episodes of concurrent LH and FSH secretion that were accompanied by detectable GnRH concentrations. This pattern resembled that reported later in dioestrus (Irvine and Alexander, 1993). By 

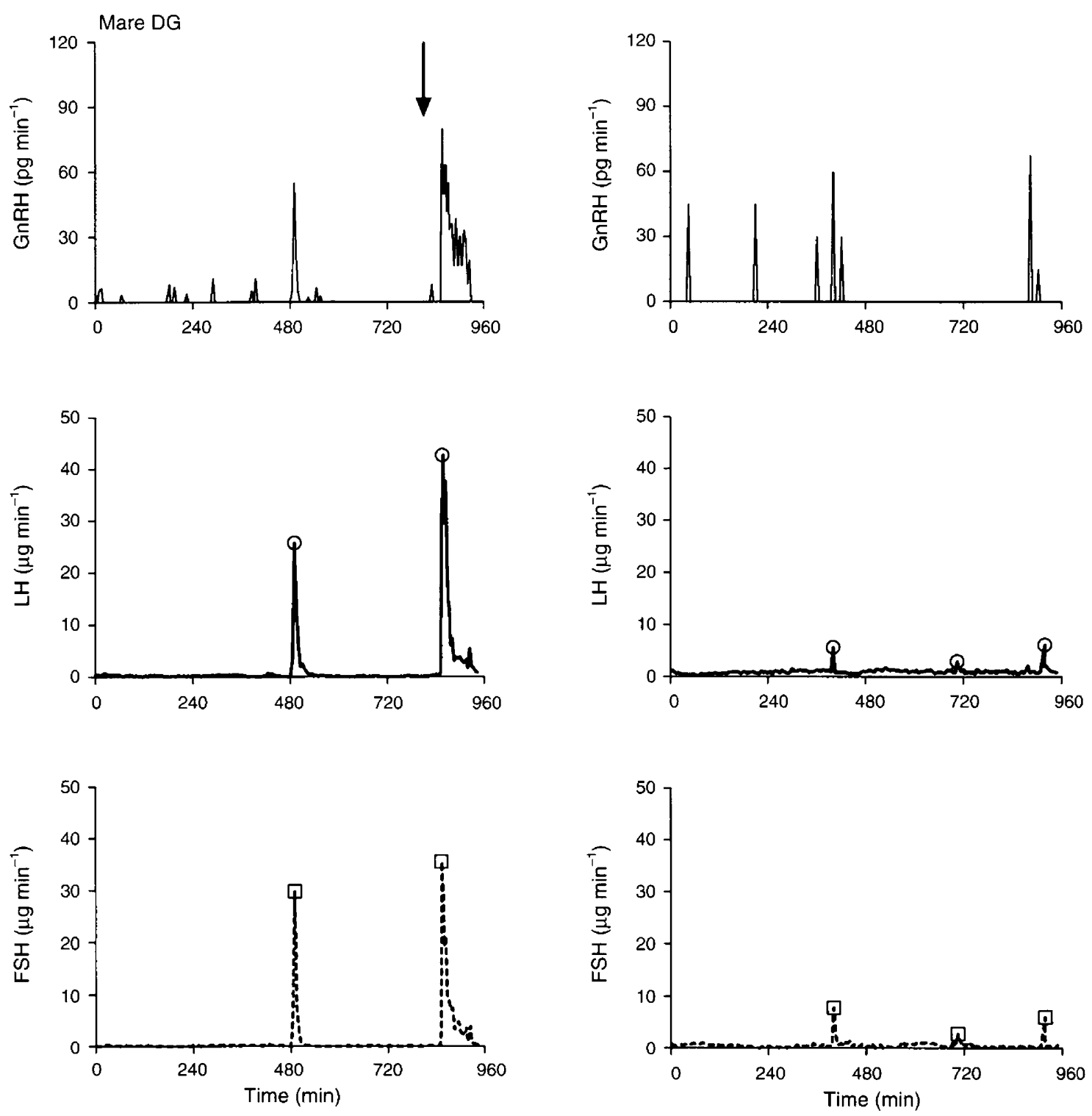

Fig. 2. Continued on following page

contrast, on the day after ovulation, $\mathrm{GnRH}$ and gonadotrophin peaks still occur approximately hourly (Irvine and Alexander, 1994). These observations suggest that progesterone negative feedback becomes effective between 2 and 3 days after ovulation in mares.

Gonadotrophin secretion continued for almost half the period between cluster-defined peaks. Using continuous sampling of pituitary venous blood, we have observed nonpulsatile LH and FSH secretion both in mid-dioestrous (Irvine and Alexander, 1993) and oestrous (Irvine and Alexander, 1994) mares. Because of limitations in $\mathrm{GnRH}$ assay sensitivity, we have been unable to determine by measuring pituitary venous concentrations whether non-pulsatile gonadotrophin secretion is nevertheless regulated by GnRH (Irvine and Alexander, 1993, 1994). This question could be better addressed by observing whether administration of a GnRH antagonist abolishes non-pulsatile gonadotrophin secretion. In any case, it seems that the slow decline in jugular gonado- trophin concentrations after ovulation is due at least in part to continued secretion between peaks. The long circulatory half-life of equine LH (Irvine, 1979) may also retard its postovulatory fall; however, available evidence suggests that this is unlikely to be the only factor involved. After the peak of the ovulatory surge, peripheral $\mathrm{LH}$ concentrations, whether measured by radioimmunoassay or in vitro bioassay, fall by less than 50\% each day (Alexander and Irvine, 1982). In the four mares studied on day 3 after ovulation in the present study, jugular $\mathrm{LH}$ concentrations fell $38 \pm 6 \%$ during the sampling period $\left(14 \pm 1 \mathrm{~h}\right.$; range, $10.5-16 \mathrm{~h}$ ) before $P_{\mathrm{CF}_{24}}$ administration. Equine $\mathrm{LH}$ is polymorphic, with isoforms differing in sialic acid content, which affects their isoelectric point, half-life and relative bioactivity (Irvine, 1979). Moreover, the circulating forms appear to vary during the ovulatory cycle (Alexander and Irvine, 1982). However, the half-lifes of isoforms at opposite extremes of the isoelectric point range from $2 \mathrm{~h}$ to $5 \mathrm{~h}$ (Irvine, 1979). It is clear that even the longest 

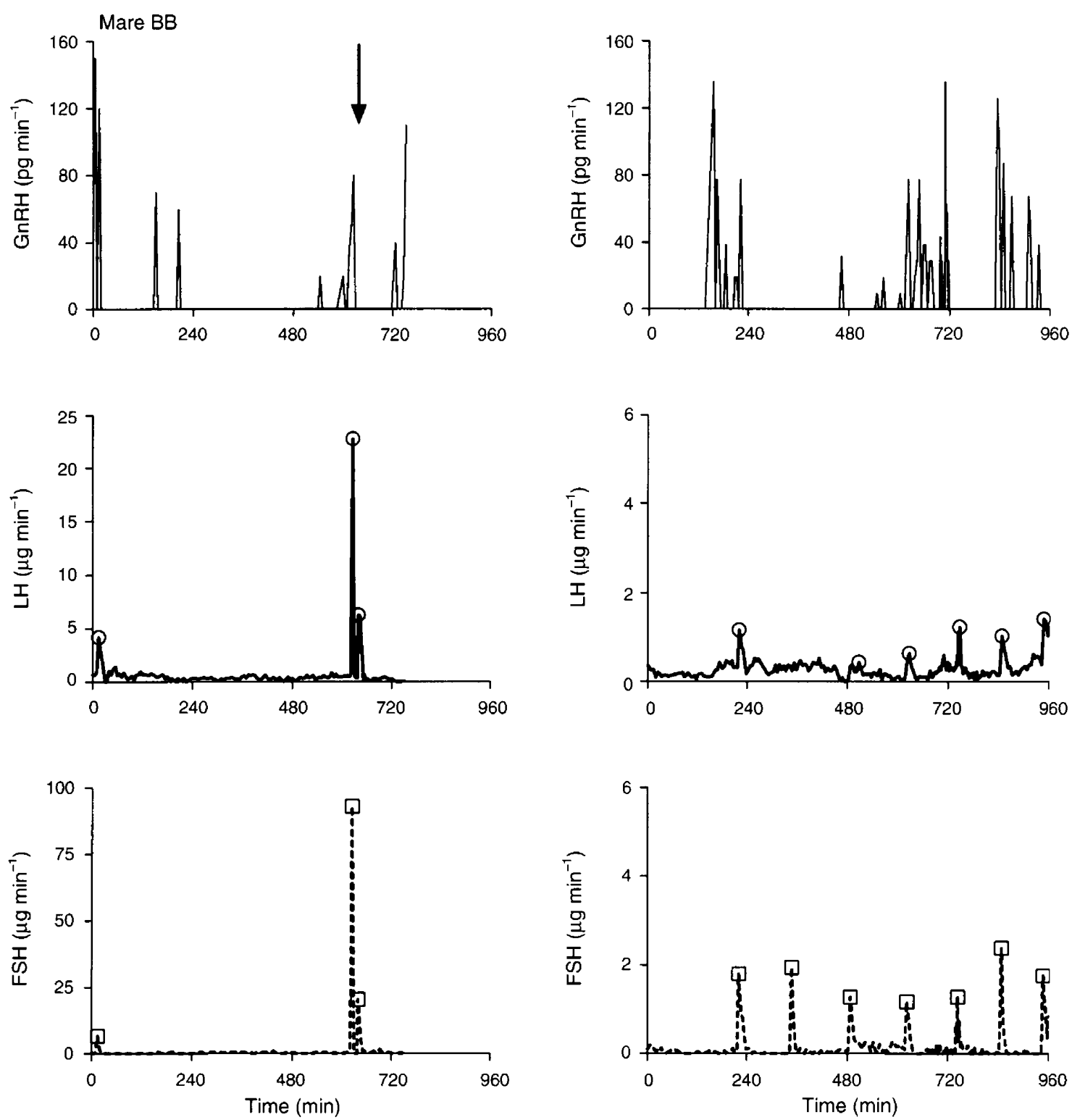

Fig. 2. Secretion rates of GnRH, LH and FSH before and immediately after prostaglandin $\mathrm{F}_{2 u}$ administration (arrow) (left panels) and commencing 20-22 $\mathrm{h}$ later (right panels) in three early dioestrous mares who had gonadotrophin peaks during both sampling periods. Secretion rates were calculated from pituitary venous blood samples collected at 2 or 5 min intervals. The maxima of gonadotrophin peaks as detected by the Cluster algorithm are marked (LH: $\bigcirc$ ) or (FSH: $\square$ ).

half-life observed is insufficient in itself to explain the slowness of the postovulatory fall in peripheral $\mathrm{LH}$ concentrations.

Lessening, but not complete removal, of progesterone negative feedback significantly raised LH and FSH peak frequency. At a mean plasma progesterone concentration of $2 \mathrm{ng} \mathrm{ml}^{-1}$, $\mathrm{LH}$ and FSH peaks were detected in pituitary venous blood once every $2.5 \mathrm{~h}$. A recent study in mares in which luteolysis was induced on day 6 after ovulation showed that by the time progesterone concentrations fall to $<\mathrm{Ing} \mathrm{ml}^{-1}$, pituitary venous LH and FSH peaks occur approximately hourly (Silvia et al., 1995). Taken together, these observations suggest that the progesterone negative feedback effect may be 'titrated' in mares; that is, concentrations need not reach a set threshold to trigger a rise in gonadotrophin peak frequency. Similarly, in cows, LH pulse frequency is directly related to blood concen- trations of natural progesterone (Roberson et al., 1989) or to the dose of synthetic progestagen given (Sanchez et al., 1995). However, this relationship has not been reported previously in mares, possibly because of the difficulty in detecting gonadotrophin pulses in peripheral blood in this species when peak frequency is rapid (Alexander and Irvine, 1987, 1994). Accordingly, after luteolysis only about half of pituitary venous peaks were identified in jugular blood in the present study, whereas no pituitary venous peaks were detected in jugular blood by Silvia et al. (1995).

LH peak amplitude declined as peak frequency rose. This result stood when hormone secretion rates were analysed that corrected for changes in ICS blood flow between days. Silvia et al. (1995) suggested a similar relationship between peak frequency and amplitude in mares but could not confirm it 
Table 1. Maximum or mean LH and FSH secretion rates (mean \pm SEM, $\mu \mathrm{g} \mathrm{min}^{-1}$ ) during peaks detected by the Cluster program in pituitary venous blood collected (every 2 or 5 min for $10.5-18.0 \mathrm{~h}$ ) from five mares studied in early dioestrus (LP) and again commencing 20-22 h after prostaglandin-induced lysis of the corpus luteum (post-PGF)

\begin{tabular}{|c|c|c|c|c|}
\hline \multirow[b]{2}{*}{ Mare } & \multicolumn{2}{|c|}{$\begin{array}{c}\text { Maximum secretion } \\
\text { rate }(n)\end{array}$} & \multicolumn{2}{|c|}{$\begin{array}{c}\text { Mean secretion } \\
\text { rate }\end{array}$} \\
\hline & Early LP & Post-PGF & Early LP & Post-PGF \\
\hline \multicolumn{5}{|l|}{ LH } \\
\hline AN & $10.5(1)$ & $2.6 \pm 0.2 \quad(12)$ & 2.8 & $0.8 \pm 0.07$ \\
\hline $\mathrm{DG}$ & $25.6(1)$ & $4.9 \pm 1.0$ & 5.1 & $1.8 \pm 0.3$ \\
\hline $\mathrm{BB}$ & $13.4 \pm 9.4(2)$ & $1.2 \pm 0.04$ & $3.9 \pm 2.2$ & $0.6 \pm 0.04$ \\
\hline $\mathrm{CR}$ & $-(0)$ & $7.5 \pm 1.1$ & - & $2.6 \pm 0.3$ \\
\hline SK & $-(0)$ & $2.4 \pm 1.1$ & - & $0.8 \pm 0.2$ \\
\hline \multicolumn{5}{|l|}{ FSH } \\
\hline AN & $11.3(1)$ & $5.1 \pm 0.7$ & 3.1 & $1.4 \pm 0.2$ \\
\hline DG & $29.6(I)$ & $3.1 \pm 1.6$ & 5.4 & $2.1 \pm 0.3$ \\
\hline $\mathrm{BB}$ & $49.5 \pm 43$ & $1.6 \pm 0.2$ & $16.3 \pm 14.9$ & $0.6 \pm 0.03$ \\
\hline CR & $-(0)$ & $3.8 \pm 0.7$ & - & $1.4 \pm 0.2$ \\
\hline SK & $-(0)$ & $3.7 \pm 1.2$ & - & $1.2 \pm 0.1$ \\
\hline
\end{tabular}

statistically since they observed only one gonadotrophin peak in its entirety before luteolysis. Moreover, they did not calculate ICS blood flow. An inverse relationship between LH peak frequency and amplitude has also been shown in other species (for example, Wildt et al., 1981; Clarke et al., 1987b).

Our study further extends the findings of Silvia et al. (1995) by demonstrating a significant decline after induced luteolysis in the maximum GnRH secretion rate accompanying gonadotrophin peaks. Nevertheless, the decrement in peak LH secretion rate exceeded that in $\mathrm{GnRH}$, suggesting that other factors, such as a fall in the number of GnRH receptors on gonadotrophs or inadequate releasable $\mathrm{LH}$ as postulated by Silvia et al. (1995), may also contribute to the reduced LH peak amplitude.

During both sampling periods, GnRH was occasionally detected without any accompanying peak in gonadotrophin secretion. Similarly, apparently ineffective GnRH release has been reported in mid-dioestrous mares (Irvine and Alexander, 1993) and ewes (Clarke et al., 1987a). The function of such GnRH secretion is unknown; however, it may serve to stimulate gonadotrophin synthesis (Clarke and Cummins, 1987). Another possibly relevant observation is that in ewes the ovulatory GnRH surge continues well beyond the surge of LH (Moenter et al., 1991). Moenter et al. (1991) suggest several possible mechanisms that could lead to this dissociation between GnRH and LH secretion, including pituitary desensitization, depletion of $\mathrm{LH}$, or the presence of factors that inhibit LH secretion.

Prostaglandin $\mathrm{F}_{2 u}$ administration induced LH and FSH secretion. It has long been known that treatment with PGF $_{2 \alpha}$ or its analogues causes an immediate but transient rise in peripheral concentrations of LH and FSH in dioestrous mares (Nett et al., 1979). This gonadotrophin increase has been thought to be mediated at least in part by increased GnRH release (Nett $e t$ al., 1979). However, in the present work in which GnRH secretion was monitored directly, the initial stimulus for $\mathrm{PGF}_{2 \alpha}$-induced gonadotrophin release did not appear to be GnRH. Similarly, we have shown in transitional-phase mares that the prostag- landin analogue, luprostiol, increases LH and FSH secretion before any detectable change in pituitary venous GnRH occurs (Joechle et al., 1987). It is possible that $\mathrm{PGF}_{2 \alpha}$ directly stimulates inositol phosphate accumulation in equine gonadotrophs as it does in ovine granulosa and luteal cells (Denning-Kendall and Wathes, 1994). Inositol phosphate production in gonadotrophs is also induced by GnRH and is correlated with LH release (Conn et al., 1987).

In summary, our findings indicate that there is effective progesterone negative feedback during the declining arm of the ovulatory LH surge in mares. The slowness of the fall in peripheral gonadotrophin concentrations in early dioestrus appears to be due at least in part to continued secretion between pulses.

The authors thank J. Turner, R. Huun and N. Shand for technical assistance. They are grateful to Hoechst AG and B. D. Schanbacher, J. F. Roser, H. Papkoff and A. F. Parlow for supplying assay reagents. This work was funded by the New Zealand Equine Research Foundation and the US National Institutes of Health (DK-38322 to C. H. G. Irvine).

\section{References}

Alexander SL and Irvine CHG (1982) Radioimmunoassay and in vitro bioassay of serum LH throughout the equine oestrous cycle Journal of Reproduction and Fertility Supplement 32 253-260

Alexander SL and Irvine CHG (1987) Secretion rates and short-term patterns of gonadotrophin-releasing hormone, FSH and LH throughout the periovulatory period in the mare journal of Endocrinology 114 351-362

Clarke IJ and Cummins JT (1987) The significance of small pulses of GnRH Joumal of Endocrinology $113413-418$

Clarke IJ, Thomas GB, Yao B and Cummins JT (1987a) GnRH secretion throughout the ovine estrous cycle Neuroendocrinology 46 82-88

Clarke IJ, Cummins JT, Crowder ME and Nett TM (1987b) Pituitary receptors for gonadotropin-releasing hormone in relation to changes in pituitary and plasma luteinizing hormone in ovariectomized-hypothalamo pituitary disconnected ewes. I. Effect of changing frequency of gonadotropin-releasing hormone pulses Biology of Reproduction 37 749-754 
Conn PM, McArdle CA, Andrews WV and Huckle WR (1987) The molecular basis of gonadotropin-releasing hormone $(\mathrm{GnRH})$ action in the pituitary gonadotropes Biology of Reproduction 36 17-35

Denning-Kendall PA and Wathes DC (1994) Acute effects of prostaglandin $F_{2 \alpha^{\prime}}$ luteinizing hormone, and estradiol on second messenger systems and on the secretion of oxytocin and progesterone from granulosa and early luteal cells of the ewe Biology of Reproduction 50 765-773

Ginther OJ (1992) Reproductive Biology of the Mare: Basic and Applied Aspects 2nd edn pp 233-290 Equiservices, Cross Plains, WI

Goodman RL and Karsch FJ (1980) Pulsatile secretion of luteinizing hormone: differential suppression by ovarian steroids Endocrinology 107 1286-1290

Hauger RL, Karsch FJ and Foster DL (1977) A new concept for control of the estrous cycle of the ewe based on the temporal relationships between luteinizing hormone, estradiol and progesterone in peripheral serum and evidence that progesterone inhibits tonic LH secretion Endocrinology 101 807-817

Irvine CHG (1979) Kinetics of gonadotrophins in the mare Journal of Reproduction and Fertility Supplement 27 131-141

Irvine CHG and Alexander SL (1987) A novel technique for measuring hypothalamic and pituitary hormone secretion rates from collection of pituitary venous effluent in the normal horse Journal of Endocrinology 113 183-192

Irvine CHG and Alexander SL (1993) Secretory patterns and rates of gonadotropin-releasing hormone, follicle-stimulating hormone, and luteinizing hormone revealed by intensive sampling of pituitary venous blood in the luteal phase mare Endocrinology 132 212-218

Irvine CHG and Alexander SL (1994) The dynamics of gonadotrophin-releasing hormone, LH and FSH secretion during the spontaneous ovulatory surge of the mare as revealed by intensive sampling of pituitary venous blood journal of Endocrinology 140 283-295

Irvine CHG, Sutton P. Turner JE and Mennick PE (1990) Changes in plasma progesterone concentrations from days 17 to 42 of gestation in mares maintaining or losing pregnancy Equine Veterinary Journal 22 104-106

Joechle W, Irvine CHG, Alexander SL and Newby TJ (1987) Release of LH, FSH and GnRH into pituitary venous blood in mares treated with a PGF analogue, luprostiol, during the transition period Journal of Reprodiction and Fertility Supplement 35 261-267

Moenter SM, Caraty A, Locatelli A and Karsch FJ (1991) Pattern of gonadotropin-releasing hormone $(\mathrm{GnRH})$ secretion leading up to ovulation in the ewe: existence of a preovulatory GnRH surge Endocrinology 129 $1175-1182$

Nett TM, Pickett BW and Squires EL (1979) Effects of Equimate (ICl-81008) on levels of luteinizing hormone, follicle-stimulating hormone and progesterone during the estrous cycle of the mare Journal of Animal Science 48 69-75

Roberson MS, Wolfe MW, Stumpf TT, Kittok RJ and Kinder JE (1989) Luteinizing hormone secretion and corpus luteum function in cows receiving two levels of progesterone Biology of Reproduction 41 997-1003

Sanchez T, Wehrman ME, Kojima FN, Cupp AS, Bergfeld EG, Peters KE, Mariscal V, Kittock RJ and Kinder JE (1995) Dosage of the synthetic progestin, norgestomet, influences luteinizing hormone pulse frequency and endogenous secretion of 17ß-estradiol in heifers Biology of Reproduction 52 464-469

Shand N, Alexander SL and Irvine CHG (1991) Comparison of the microheterogeneity of horse LH and FSH in the pituitary with that secreted into pituitary venous blood at oestrus Journal of Reproduction and Fertility Supplement 44 1-11

Silvia PJ, Meyer SL and Fitzgerald BP (1995) Pulsatile gonadotropin secretion determined by frequent sampling from the intercavernous sinus of the mare: possible modulatory role of progesterone during luteolysis Biology of Reproduction 53 438-446

Soules MR, Steiner RA, Clifton DK, Cohen NL, Aksel S and Bremner WJ (1984) Progesterone modulation of pulsatile luteinizing hormone secretion in normal women Journal of Clinical Endocrinology and Metabolism 58 378-383

Stabenfeldt GH, Daels PF, Munro CJ, Kindahl H, Hughes JP and Lasley B (1991) An oestrogen conjugate enzyme immunoassay for monitoring pregnancy in the mare: limitations of the assay between days 40 and 70 of gestation Journal of Reproduction and Fertility Supplement 44 37-44

Townson DH, Pierson RA and Ginther OJ (1989) Characterization of plasma progesterone concentrations for two distinct luteal morphologies in mares Theriogenology 32 197-204

Veldhuis JD and Johnson ML (1986) Cluster analysis: a simple, versatile and robust algorithm for endocrine pulse detection American Journal of Physiology 250 E486-E493

Wildt L, Hausler A, Marshall G, Hutchinson JS, Plant TM, Belchetz PE and Knobil E (1981) Frequency and amplitude of gonadotropin-releasing hormone stimulation and gonadotropin secretion in the rhesus monkey Endocrinology $109376-385$ 